sources: U.S. Government agencies, numerous industrial companies, charitable foundations, and scientific institutions. These donors join Professor Bronk and me, for the National Academy of Sciences, in a most hearty welcome and with best wishes for a successful and profitable meeting.

After thanking Dr Menzel for his address, Dr Goldberg then invited Dr D. H. McLaughlin, Regent of the University of California, to speak.

\title{
ADDRESS BY THE REPRESENTATIVE OF THE UNIVERSITY OF CALIFORNIA,
}

DR D. H. MCLAUGHLIN

\section{Dr Oort and Members of the International Astronomical Union:}

On behalf of the President and the Regents of the University of California, I welcome you most cordially to our Berkeley campus. We are very pleased that you have elected to hold your second meeting in the United States after an interval of twenty-nine years. Your selection of this once remote site on the far western side of the North American continent is truly a gracious recognition on your part of the value of the contributions that the staff of the University of California has made to the advancement of astronomy and the sciences on which it depends to such an increasing degree.

The University of California is a relatively young institution. Less than a century ago, this plaza, in which we are gathered this morning, was an open field-a sunny spot on the long, grassy slope from the hills to the bay which was then unbroken except for scattered clusters of oaks and a few low buildings at the distant landing. Yet, in that short time, a University has been created that has won a respected place among institutions of learning in the world, and our setting has been transformed from its quiet emptiness to the extensive urban region that surrounds us.

In a century of growth such as this, when this pleasant land with its mild Mediterranean climate was being rapidly filled with energetic people who built cities, developed vast orchards, farms and ranches and created a host of industries, it might have been expected that emphasis on the practical needs of life would have completely diverted attention from scholarly or scientific interests. Fortunately, it did not, for even in its earliest days the University was generously supported not only by the people of the state through their legislature, but by individuals whose gifts made possible the prompt initiation of work in many fields that otherwise might have been cultivated much more slowly. Among them was the bequest of James Lick from which the first structures of the observatory that bears his name was built and which provided California with the first great refracting telescope that enabled the young institution to attract and hold astronomers of highest competence.

It is, I think, particularly significant that this early benefaction-in fact one of the very first the University received-was to support a science that could hardly be expected to pay its way in direct service to the needs of the growing state. Its appeal was solely intellectual and it is surely greatly to the credit of the spirit of the early pioneer days that men were stirred by such visions and that the people at large through their representative bodies provided the continued financial means necessary to carry on the work that the private donors had started.

Men tend to express their gratitude for material wealth-or perhaps their pride in it-in many different ways, some admirable, some otherwise. The Spanish conquerors and settlers, from California to Peru, were inclined to build churches and many a mining town is richly 
adorned with worthy examples of the architecture of the sixteenth to eighteenth centuries that achieved some of its loveliest expressions on the Pacific side of the Americas. In Mexico, towns such as Guanajuato or Tasco, built near the bonanzas of silver-or the town of Huancavelica in Peru where great deposits of quicksilver were mined-are adorned with numerous churches with rich facades and towers that are still a joy to see. Their contruction was an expression of the desire of those who had been made affluent by the precious metals they had won from the earth to express their belief in something more enduring than mere wealth-or perhaps to record their repentance for some aspects of their behavior when they were winning their wealth.

We can be grateful for the beauty of the early churches and monuments left us by the Spaniards-and they are particularly good to have in this age when most of the fine arts are so sterile-but we can be even more appreciative of the early Americans in California who very wisely gave their support to schools, to laboratories and to the creation of instruments for observation and precise measurement. Our forebears here, who had comparable good fortune in the mines and in the early development of the country, perhaps showed less skill in architecture, but they were equally eager to find a worthy way to make an adequate return for the riches they had won in this new and growing land.

Devotion of fortunes to such causes was truly an act of faith, and that to me is far more impressive than the earlier expression of belief through the building of churches, worthy though it may have been.

It was faith in the scientific method that led to the generous support astronomy has received here and elsewhere, and particularly faith in the men who are called scientists. And today, even more, the generous support of our laboratories and observatories reveals the same deep trust in the ends of science and in the integrity of the men who are devoted to it.

The acceptance of the concepts of modern astronomy requires faith of the highest order on the part of a layman - faith in the accuracy of instruments, in the precision of measurements and in the interpretation of seemingly obscure data. The acceptance of the idea that a distant star is receding from us at some fantastic speed simply from the observation of the displacement of a line on a spectrogram must remain an act of faith on the part of most non-scientistseven on the part of those whose learning in the humanities may be profound. But the faith is widely held, and continues to be demonstrated by the persistent and growing respect and steady support given to the work of men, such as yourselves, whose devotion to the highest ideals of science is unquestioned.

The existence of this Union, however, is not only an expression of such confidence on the part of men, but is also a demonstration that devotion to the ideals of science and belief in the integrity of fellow scientists is not restricted to national boundaries. Through it, the intellectual unity of competent and thoughtful individuals of all nations and races should be made clear to the smaller minds that would create dissention. From its example, we can find hope even in times as troubled as the present, that wise co-operation for worthy ends will displace strife, that competition will be fair, generous and exciting, and that faith in the men of science will be justified.

As the high priests of this great cult-if I may use these words in a new and better senseyou are indeed welcome here and we are proud to be your hosts.

The Chairman thanked Dr McLaughlin and then invited Professor J. H. Oort, President of the Union, to address the gathering. 